\title{
Permafrost table depth in soils of Eastern Antarctica oases, King George and Ardley Islands (South Shetland Islands)
}

\author{
Ivan Alekseev ${ }^{*}$, Evgeny Abakumov \\ Saint Petersburg State University, Department of Applied Ecology, $16^{\text {th }}$ line of Vasilevsky \\ island, 29, 199178, Saint Petersburg, Russia
}

\begin{abstract}
This study was aimed to investigate the electrical resistivity in soils and permafrost of various ice-free areas of Antarctica and Sub-Antarctica (from coastal Eastern Antarctica oases to Maritime Antarctica). Measurements of electrical resistivity of soil and permafrost strata were performed with a portable device LandMapper. It was found that the permafrost table depth ranged 82 to $106 \mathrm{~cm}$ in Bunger Hills, 95 to $122 \mathrm{~cm}$ in Larsemann Hills, 27 to 106 in Thala Hills, and 89 to $100 \mathrm{~cm}$ on King George Island and Ardley Island. Presence (and thickness) of organic layer and influence of snow patches melting were found the main reasons for differentiation of permafrost table depth in the studied ice-free areas. Anthropogenic disturbance at waste disposal sites resulted in more pronounced soil profile heterogeneity and formation of scattered electrical resistivity profiles. Permafrost layer was found less homogenous in the upper part of permafrost strata compared to the lower part. An application of vertical electrical resistivity sounding (VERS) may be very useful for evaluation of active layer thickness in Antarctic environments, especially when they are facing severe anthropogenic influence due to maintaining of numerous Antarctic research stations and logistical operations
\end{abstract}

Key words: Antarctica, soils, electrical resistivity, permafrost table, active layer

DOI: $10.5817 / C P R 2020-1-2$

\section{Introduction}

Three climatic zones can be distinguished in Antarctica (Bockheim and Hall 2002): Subantarctic (including the South Shetland Islands), Antarctic coastal and Antarctic continental zone. In general, Antarctica weakly obeys the general geographic law of latitudinal zoning. Remote ice- free areas (oases) are isolated from each other and have no biological or even climatic connection, so they are more like islands in the ocean.

The main limiting factor for soil formation in Eastern Antarctica oases is the lack of moisture. Melting snow in the sum-

\footnotetext{
Received November 18, 2019, accepted April 29, 2020.

*Corresponding author: I. Alekseev < alekseevivan95@gmail.com>

Acknowledgements: This study was supported by Russian Foundation for Basic Research, grant 18-04-00900 "Ornithogenic soils of Antarctica: formation, geography, biogeochemistry and bioindication", grant 19-54-18003 "Assessment of regional contribution of Antarctic soils into global carbon balance considering stabilization and humification of organic matter" and Grant of Saint Petersburg State University "Urbanized ecosystems of the Russian Arctic: dynamics, state and sustainable development". The authors gratefully acknowledge Russian Antarctic Expedition, especially the head of seasonal expedition 2017-2018 V.N. Churun, for providing scientific and logistic support during the field work.
} 
mer months is the determining regulator of bio- and pedological diversity (Mergelov et al. 2015). The other sources, i.e. liquid precipitation, and low air humidity are much less effective compared to melt water available from snow patches during austral summer season.

Eastern Antarctica oases are characterized by climatic extremality, which in turn determines the specificity of soil formation. Lack of moisture, UV radiation, rapid temperature changes, and strong winds significantly reduce the primary production of organic matter and the formation of organogenic horizons on the surfaces of loose and rocky substrates that prevail in Eastern Antarctica oases (Mergelov et al. 2015). An important feature of the landscapes of the oases is that most of the soil biomass is concentrated beneath the mineral surface, which greatly changes the vertical organization of the soil strata.

Due to the higher air temperature and the amount of liquid precipitation in Subantarctic than Arctic regins, the soils are strikingly different from those described in coastal oases of Eastern Antarctica. Frequent transitions of soil temperature through zero values, frequent cycles of freezing-thawing of soil may cause intensive degradation of parent materials. At the same time, the availability of moisture and high biological activity increase the role of biological and chemical weathering of rocks, as well as the content of organic carbon in soils. In addition, all the conditions mentioned above lead to the formation of clay secondary minerals.

Climate change effects in polar regions has been accelerated in last decade. Permafrost properties and active layer dynamics are two key indicators of climate change in the polar region (Burgess et al. 2000). However, distribution and properties of permafrost and active-layer dynamics in the Subantarctic region are still poorly understood. Circumpolar Active Layer Monitoring (CALM) program, which is aimed to observe the response of the active layer and near-surface permafrost to climate change over long (multi-decadal) time scales covers, consist of more than 200 sites in both hemispheres. Recently, review on active layer monitoring in Antarctica was published (Hrbáček et al. 2018). The authors point out the spatial, qualitative and quantitative differences on monitoring data derived in various regions of Antarctica. Moreover, they mention that information on the active layer depth is still sparse in many regions and the monitoring needs to be extended. That is why the development of uniform non-direct methods for monitoring of permafrost is required.

Results on the thermal state of permafrost and the active layer in the Antarctic are presented in Vieira et al. (2007). The authors show that permafrost temperatures are much lower in continental Antarctica. A review work on recent advances in studying active layer was presented by Oliva et al. (2017). Comprehensive study of geocryological conditions of Antarctica revealed regional severity consequence from sub-Antarctic islands, Bunger Hills, Schirmacher Hills, Larsemann Hills, Thala Hills, Marie Byrd Land, Wilson Hills (Abramov et al. 2011).

Air and surface temperatures are permanently recorded at the year-round polar stations, however, data on temperature regime of soils are very limited (Gilichinsky et al. 2010). Study of Abakumov and Andreev (2011) focused on soil temperature regime of King George Island. They showed how different plant communities (lichens, mosses, vascular plants) density affect the period of biological activity $\left(\mathrm{t}>5^{\circ} \mathrm{C}\right)$. The organogenic horizon of soil under Deschampsia antarctica shows higher mean annual temperatures, however, it is warming up slower than organogenic horizons under lichens and mosses. The role of topography in active layer dynamics has been studied by Oliva et al. (2017). It was shown that topography has a strong influence on snow cover duration, which in turn affects frozen ground conditions. 
Conventional methods of soil analysis, which are widely used in modern soil science, usually require the collection of disturbed soil samples (from soil profile) and subsequent laboratory analysis (Murad 2012). Electrical geophysical methods, such as self-potential (SP), four electrode probe method, electrical profiling (EP), vertical electrical resistivity sounding (VERS), and non-contact electromagnetic profiling(NEP) allow to perform rapid measurements of soil electrical properties, such as electrical conductivity and electrical resistivity (ER) directly from the soil surface to any depth without any disturbance of soil cover. The method could be applied in e.g. determination of soil salinization and excess moisture in different environments (Pozdnyakov 2008), soil texture mapping (Triantafilis and Lesch 2005); assessment of coarse element content in soils (Tetegan et al. 2012); the study of soil structure and compaction (Besson et al. 2004), prognosis of floodings in urban areas (Smernikov et al. 2008), investigation of urban soils (Pozdnyakov and Eliseev 2012), or agricultural management (Jaynes et al. 2005, Andrenelli et al. 2013, André et al. 2012). Previously VERS methodology was used for comprehensive study of soil electrical properties in conditions of the Arctic (Alekseev and Abakumov 2016, Alekseev et al. 2017). These investigations showed that VERS can be used for non-direct identification not only of soil-permafrost boundary, but also for specification of various geochemical regimes and pedoenvironments serving a useful tool for soil diagnostics as well. VERS have been used for the assessment of the

\section{Material and Methods}

VERS measurements were conducted during the $63^{\text {rd }}$ Russian Antarctic Expedition (December 2017-April 2018). Studies were conducted in Thala Hills, Larsemann ground water level in grounds (Samouëlian et al. 2005), ground water contamination (Karlik et al. 2001), and mapping of oil spills in Antarctic environments (Pettersson and Nobes 2003).

Recently, permafrost-affected soils are of increased interest in context of studying their electrical properties. Indeed, for seasonal-freezing soils of zonal sequence it makes sense to discuss electrical properties in context of their correlation with such basic soil parameters as organic carbon content, cation exchange capacity, or physical clay content. However, permafrost-affected soils have a huge difference in ER values between soil layer and permafrost layer. Therefore, finding clear relationships between ER and basic soil parameters is not easy. Based on several investigations performed, we can draw a valid conclusion that ER values are about 10005000 S.m for permafrost layer, while unfrozen clayey and sandy layers of soil are characterized by much lower values (Pozdnyakov 2008, Gibas et al. 2005, Hauck et al. 2003, Michels Turu and Ros Visus 2013, Smernikov et al. 2008, Vanhala et al. 2009).

The aim of this study was to determine the electrical resistivity properties of Antarctic soils affected by permafrost and ornithogenic factor. The objectives of the investigation were: (1) to determine soil elecrical properties using vertical electrical resistivity sounding $(V E R S),(2)$ to evaluate the correctness of used method for further use with a special respect to future environmental monitoring and fast soil analyses.

Hills, Bunger Hills, on King George Island (Fildes Peninsula) and specially protected natural area of Ardley Island (South Shetland Islands) (Fig. 1). 


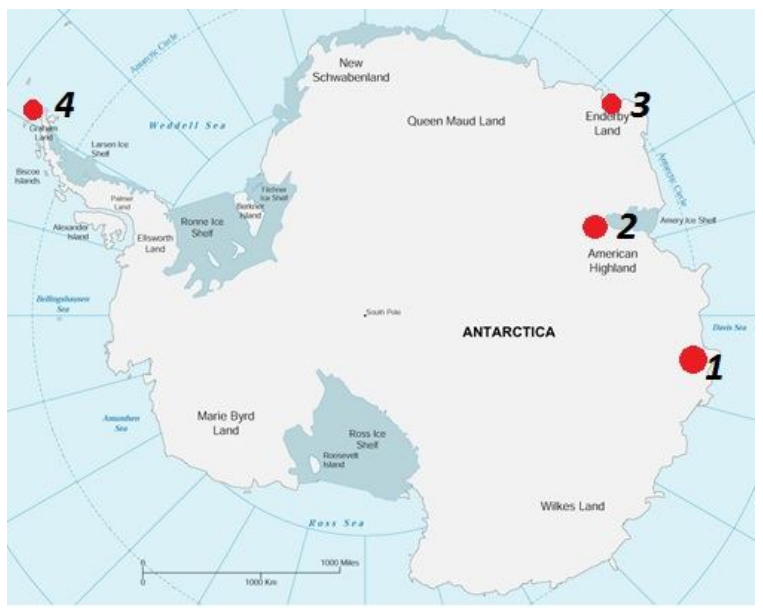

Fig. 1. The map of investigated regions. Note: 1 - Bunger Hills, 2 - Larsemann Hills, 3 - Thala Hills, 4 - King George and Ardley Island.

King George Island is the largest island of the South Shetland Islands archipelago. The relief of the southeastern part of the island is strongly dissected, has a number of bays. Most of the island is covered by a glacier. Numerous hills are composed of volcanic rocks (strongly eroded). According to eco-climatic zoning, King George Island refers to the Antarctic Peninsula in a part that is located north of the isotherm of average annual temperatures of $-1^{\circ} \mathrm{C}$. The island is located in the natural zone of Maritime Antarctica (Terauds et al. 2012).

Soil formation is largely possible only at the tops of the hills and remnants, and also in the coastal parts characterized by a milder climate. Parent materials are presented by andesites, basalts and tuffs, the coastal areas is covered by maritime sands and gravels, while the periglacial plots are occupied by moraines and some fluvioglacial materials. Mosses, lichens, algae are typical for most of the island's habitats. In some parts of the island, two species of vascular plants occur - Deschampsia antarctica and Colobanthus quitensis. Penguins, seals, seabirds are abundant in the coastal habitats of the island, and play a crucial role in soil development (Michel et al. 2006, Simas et al. 2007, Abakumov and Alekseev 2018).

Ardley Island $\left(62^{\circ} 13^{\prime} \mathrm{S}, 58^{\circ} 54^{\prime} \mathrm{W}\right)$ is located on the south-west coast of King George Island, $500 \mathrm{~m}$ east of the coast of the Fildes Peninsula in Maxwell Bay (Fildes Bay). The area is represented mainly by andesite-basalt lavas and tuffs belonging to the Tertiary. Several elevated terraces-beaches are also described. Ardley Island is, thanks to high biodiversity, Antarctic Special Protected Area (ASPA). A wide variety of seabirds arrive in the area during the breeding period (11 species) or molting. Ardley Island also features a welldeveloped and noticeable flora, including several species of lichens, mosses and vascular plants. The most common lichens in this area are Himantormia lugubris and Usnea genera, which dominate the higher parts of Ardley Island, as well as Placopsis sp., Xanthoria sp., Haematomma sp., Rinodina sp., Caloplaca sp. and Buellia sp. which occur.

Larsemann Hills oasis (East Antarctica) is deeply dissected by short (up to $1 \mathrm{~km}$ ) valleys, which formed along the lineaments 
as a result of glacial erosion (Mergelov 2014). Inter-mountain valleys are the most important structural element of the oasis, because they serve as a landscape background for wet valleys formation. The main feature of the climate of this oasis is persistent, strong winds blowing from the north-east during most of summer days. Some data contains information on serious storm winds with speeds up to $50 \mathrm{~m} / \mathrm{s}$. Many freshwater lakes of various size, depth and biodiversity have been described in Larsemann Hills. Geologically this oasis mostly consists of gneisses, crystalline shale.

Bunger Hills (East Antarctica) consists of a complex of islands and inlets on the inner shelf overlain by morainic drift and notably ice free throughout the year, lying south of the Highjump Archipelago. Oasis is surrounded by glaciers. Rocks are represented mainly by gneiss, granite and migmatite. Bunger Hills form a line of summits of $130-150 \mathrm{~m}$ high in the south which deflect the ice flow to west and east. The summits decline northwards and reflect a preglacial erosion surface. Southern part of oasis contains several fault-oriented glacial lakes (Colhoun and Adamson 1992). Lichen and moss presence and growth is mostly limited to melt streams often associated with periglacial cracking and south-facing rock slopes close to the Apfel Glacier.

Thala Hills (East Antarctica) are low, rounded coastal hills between Freeth and Spooner Bays in Enderby Land, Antarctica. It is a hilly area with several ridges (relative height of 10-40 m). Depressions located between these ridges are mostly filled with lakes, snow patches and local glaciers. Oasis is underlain by granulite-facies metamorphic and plutonic rocks of the Proterozoic Rayner complex (Black et al. 1987). Additional water inflow from melting snow patches during the warm season is the most important factor of soil formation in the warm season. Wind shelters in the rock baths are found as places with the highest biomass comprising of bryophytes (Mergelov 2014).

The main climatic parameters for studied regions are specified in Table $1 . \mathrm{Re}$ gional variation especially in air temperatures and precipitation rates can be distinguished between Eastern and Western Antarctica ice-free areas.

\begin{tabular}{|c|c|c|c|c|}
\hline $\begin{array}{c}\text { MAAT } \\
\left({ }^{\circ} \mathrm{C}\right)\end{array}$ & $\begin{array}{c}\text { MAST } \\
\left({ }^{\circ} \mathrm{C}\right)\end{array}$ & $\begin{array}{c}\text { MAGT } \\
\left({ }^{\mathbf{o}} \mathrm{C}\right)\end{array}$ & $\begin{array}{c}\text { Mean annual } \\
\text { wind speed }\left(\mathrm{m} \mathrm{s}^{-1}\right)\end{array}$ & $\begin{array}{c}\text { Annual precipi- } \\
\text { tation (mm) }\end{array}$ \\
\hline \multicolumn{5}{|c|}{ Bunger Hills } \\
\hline-9.0 & -8.8 & -7.8 & 6.8 & 204 \\
\hline \multicolumn{5}{|c|}{ Larsemann Hills } \\
\hline-9.6 & -10.4 & -9.1 & 6.7 & 250 \\
\hline \multicolumn{5}{|c|}{ Thala Hills } \\
\hline-11.0 & -8.2 & -8.1 & 10.3 & 250 \\
\hline \multicolumn{5}{|c|}{ King George and Ardley Island } \\
\hline-2.3 & -0.3 & - & 9.3 & 729 \\
\hline
\end{tabular}

Table 1. Climatic parameters of studied regions (according to data provided by ROSHYDROMET [1]). Note: MAAT - Mean Annual Air Temperature, MAST - Mean Annual Surface Temperature, MAGT - Mean Annual Ground Temperature. 
Classification of soils was carried out according to World Reference Base for Soil Resources ([2] - FAO 2014). It should be noted that issues related to the classification of Antarctic soils are still debatable, disputes are being held regarding the validity of distinguishing of certain types of soils.

VERS were performed using four-electrode $(\mathrm{AB}+\mathrm{MN})$ arrays of the AMNB configuration with use of the Schlumberger geometry and portable device Landmapper ERM-02 (Landviser, LLC). The device can measure electrical resistivity in a surface soil layer of the depth from $2 \mathrm{~cm}$ potentially down to $20 \mathrm{~m}$, which is set by varying the size of a four-electrodes probe. $V E R S$ was used to study the upper 0 to $3 \mathrm{~m}$ thick layer in greater detail. The distance between the $\mathrm{A}$ and $\mathrm{B}$ electrodes ranged from 10 to $600 \mathrm{~cm}$ while the distance between the $\mathrm{M}$ and $\mathrm{N}$ electrodes was constant: $10 \mathrm{~cm}$. The electrodes were situated on the soil surface with a depth of penetration into soil about $0.5 \mathrm{~cm}$. The geometric factor $\mathrm{K}$ was first calculated for all the electrode spacing using the formula:

$$
K=\pi(L 2 / 2 b-b / 2)
$$

Eqn. 1

for the Schlumberger array with $\mathrm{MN}=2 \mathrm{~b}$ and $1 / 2 \mathrm{AB}=\mathrm{L}$.

For processing and visualization purposes a 1D layer model (ZondIP software, Geodevice, Saint Peterburg) have been used. Zondip1d software has been used for processing and modelling of electrical resistivity Zondip1d is aimed to one-dimensional resistivity and induced polarization vertical electrosounding data interpretation. Basis for this software is the conception of multi-station interpretation. Profile line data is considered as a reflection of geological section. It means that multistation data of profile line is whole, and not set of separated curves. This model provides the data on apparent electrical resistivity values changes with the depth $(\rho)$, the layers thickness (h) and layer depth (z). Field data on electrical resistivity are presented by 3 values from each measured point. The values obtained were then multiplied with the resistance values to obtain the apparent resistivity, $\rho a$, values. Then the apparent resistivity, $\rho a$, values were plotted against the electrode spacing's
$(1 / 2 \mathrm{AB})$ on a $\log -\log$ scale to obtain the $V E R S$ sounding curves using an appropriate computer software ZondIp (Geodevice, Saint Petersburg). The VERS data and their modeling have been used to derive the geoelectric sections for the various profiles. Three resistivity sounding curve types were obtained from the studied area.

Two objects from each of studied regions were chosen for detailed analysis of electrical properties (Table 2). Additionally, disposal waste site in surroundings of Bellingshausen station was also analyzed. Coarse fraction content was ranged from $20 \%$ (in loamy Ornithic Stagnic Cryosol of Ardley island) to $75 \%$ (in Skeletic-turbic Cryosol in Bunger Hills).

They are located in different geomorphological positions ranging from marine terrace or elevated sites on the top of flat hills (King George and Ardley Island) to relatively flat sites in Eastern Antarctica oases (Fig. 2). 


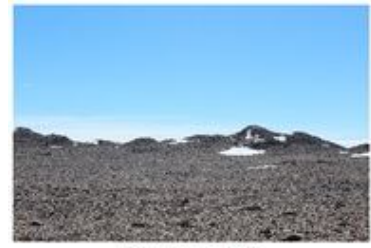

Bunger 1

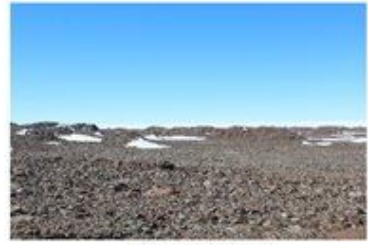

Bunger 2

Larsemann Hills

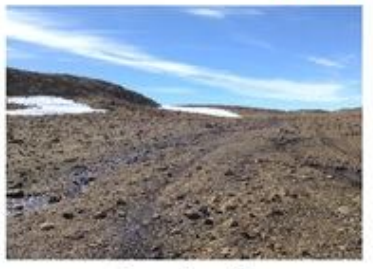

LarsJan1

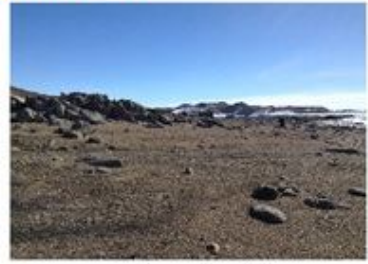

LarsJan8

Thala Hills

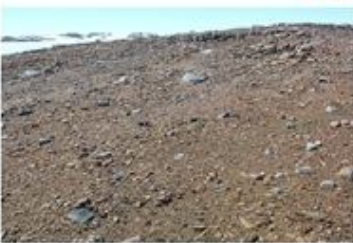

Ant2

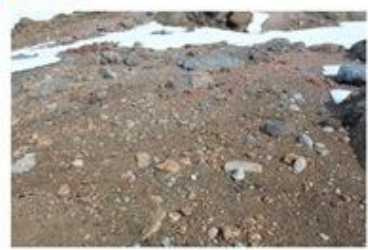

Ant10

King George and Ardley Island

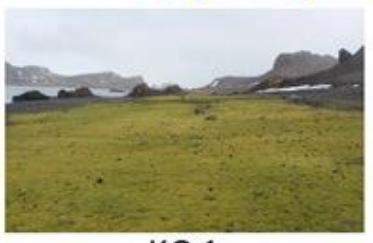

KG 1

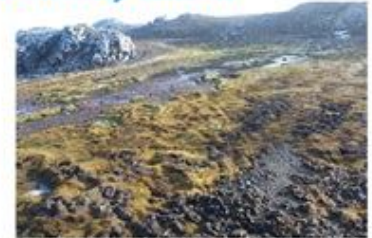

Ardley 1

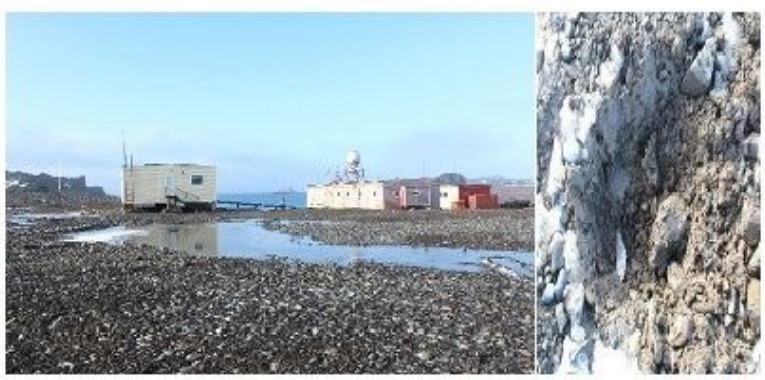

Waste disposal site, surroundings of Bellingshausen station, King George Island

Fig. 2. Studied objects. 


\begin{tabular}{|c|c|c|c|}
\hline Soil profile ID & Coordinates & WRB name & Coarse fraction $(\%)$ \\
\hline \multicolumn{4}{|c|}{ Bunger Hills } \\
\hline Bunger 1 & $\begin{array}{c}\text { S } 66^{\circ} 28^{\prime} 02,5^{\prime \prime} \\
\text { E } 100^{\circ} 76^{\prime} 05,7^{\prime \prime}\end{array}$ & $\begin{array}{l}\text { Skeletic-turbic } \\
\text { Cryosol }\end{array}$ & 75 \\
\hline Bunger 2 & $\begin{array}{c}\mathrm{S} 66^{\circ} 26^{\prime} 02,7^{\prime \prime} \\
\mathrm{E} 100^{\circ} 76^{\prime} 24,1^{\prime \prime}\end{array}$ & $\begin{array}{l}\text { Skeletic-turbic } \\
\text { Cryosol }\end{array}$ & 72 \\
\hline \multicolumn{4}{|c|}{ Larsemann Hills } \\
\hline LarsJan1 & $\begin{array}{l}\text { S } 76^{\circ} 34^{\prime} 21,2^{\prime \prime} \\
\text { E } 69^{\circ} 40^{\prime} 23,2^{\prime \prime}\end{array}$ & $\begin{array}{l}\text { Stagnic-leptic } \\
\text { Cryosol }\end{array}$ & 65 \\
\hline LarsJan 8 & $\begin{array}{l}\text { S } 76^{\circ} 34^{\prime} 43,1^{\prime \prime} \\
\text { E } 69^{\circ} 40^{\prime} 17,2^{\prime \prime}\end{array}$ & Lithic Cryosol & 58 \\
\hline \multicolumn{4}{|c|}{ Thala hills } \\
\hline Ant2 & $\begin{array}{l}\text { S } 67^{\circ} 40^{\prime} 02,9^{\prime \prime} \\
\text { W } 45^{\circ} 51^{\prime} 32,5^{\prime \prime}\end{array}$ & Lithic Cryosol & 71 \\
\hline Ant10 & $\begin{array}{l}\text { S } 67^{\circ} 40^{\prime} 07,3^{\prime \prime} \\
\text { W } 45^{\circ} 50^{\prime} 44,7^{\prime \prime}\end{array}$ & $\begin{array}{l}\text { Skeletic-turbic } \\
\text { Cryosol }\end{array}$ & 65 \\
\hline \multicolumn{4}{|c|}{ King George and Ardley Island } \\
\hline KG 1 & $\begin{array}{l}\text { King George island } \\
\text { S } 62^{\circ} 13^{\prime} 46,4^{\prime \prime} \\
\text { W } 58^{\circ} 58^{\prime} 36,4^{\prime \prime}\end{array}$ & $\begin{array}{l}\text { Histic Cryosol on } \\
\text { stratified substrata } \\
\text { of marine terrace }\end{array}$ & 55 \\
\hline Ardley 1 & $\begin{array}{c}\text { Ardley island } \\
\text { S } 62^{\circ} 11^{\prime} 48,5^{\prime \prime} \\
\text { W } 58^{\circ} 56^{\prime} 32,1^{\prime \prime}\end{array}$ & $\begin{array}{l}\text { Ornithic Stagnic } \\
\text { Cryosol on loamy } \\
\text { material }\end{array}$ & 20 \\
\hline Waste Disposal & $\begin{array}{l}\text { King George island } \\
\text { S } 62^{\circ} 11^{\prime} 55,3^{\prime \prime} \\
\text { W } 58^{\circ} 57^{\prime} 31,1^{\prime \prime}\end{array}$ & $\begin{array}{c}\text { Turbic Cryic } \\
\text { Technosol on } \\
\text { mixed natural and } \\
\text { waste materials }\end{array}$ & 35 \\
\hline
\end{tabular}

Table 2. Geographical and pedological information of studied objects. 


\section{Results and Discussion}

Data obtained showed that the measured electric resistivity reflects well the profile heterogeneity of soils investigated (Fig. 3, Table 3).

The analysis of changes of the apparent resistivity in the permafrost reveals several tendencies. The major is a monotonous increase in the $\rho_{\mathrm{a}}$ values with the depth. At the contact of permafrost with the active layer, a sharp increase in the apparent resistivity from hundreds $\Omega$.m to thousands and dozens of thousand $\Omega . m$ takes place. The vertical profiles of the apparent resistivity are generally characterized by gradual decrease (complicated by few small peaks) down to the profile with abrupt change and maximum values in permafrost layer. Our data on electrical resistivity in permafrost-affected soil coincides with those, published by McGinis and Jensen (1971) and Kasprzak (2015) who have showed that increased values of electrical resistivity are related to the permafrost table. The average active layer thickness was found the same in both soils of pristine and

\section{King George and Ardley Island}

Soil situated in marine terraces of King George Island (KG) had relatively low values of ER compared to inland sites. This could be explained by possible accumulation of salts due to more pronounced impulverization. ER profile is quite homogenous which is explained by low rates of soil stratification and less pronounced changing of soil texture and composition, correspondingly. Permafrost table depth was found as $89 \mathrm{~cm}$ for this site.

The electrical resistivity profile of ornithogenic soil (Ardley 1) is more homogenous which can be related to the less pronounced turbic processes within the soil profile. However, a peak of ER value at the depth of $95 \mathrm{~cm}$ was found. This can be explained by higher influence of perma- anthropogenic environments.

Typically, values of apparent electrical resistivity (ER) increase rapidly on the active layer -permafrost border at the depths of $80-100 \mathrm{~cm}$ (from hundreds to thousands

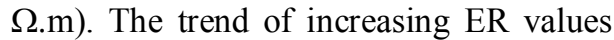
within the permafrost strata can be explained by morphological reason (increasing of homogeneity in permafrost layer down to the depth). The number and size of cracks in permafrost are also decreasing to the depth. This explains lower amounts of water, iron oxides, dissolved organic matter accumulated in lower parts of permafrost layer compared to the gleyicpermafrost geochemical border (Abakumov and Tomashunas 2016). Fluctuations in ER values within permafrost strata may be connected with its instability and irregularities. Similar trends have been described earlier in soils of the northern part of the Gydan peninsula (Abakumov and Tomashunas 2016) and with the soils of Antarctica (Abakumov and Parnikoza 2015).

frost in this supra-permafrost layer (about $10 \mathrm{~cm}$ ) and more pronounced turbic process. Lower values of ER in top $100 \mathrm{~cm}$ soil layer here is explained by higher clay material content, which is well correlated with previously obtained data (Pozdnyakov 2008, Marchenko 2007). Permafrost table depth is $100 \mathrm{~cm}$ at this site.

Soil of waste disposal site showed high heterogeneity of electrical resistivity profile due to coupled natural and humancaused turbation of soil mass. Very low electrical resistivity values in topsoil at this site are caused by overmoistening (high amount of gravitational type of water), which coincides with the data reported previously (Samouëlian et al. 2005, Pozdnyakov 2008, Magnin et al. 2015). Perma- 
frost table depth is about $100 \mathrm{~cm}$ at this site. Permafrost layer are characterized by complicated ER profile, which may be

\section{Bunger Hills}

Profile distribution of electrical resistivity values in Bunger Hills is mostly explained by high pronounced cryoturbation process in soils studied and salt staining (most probably due to tightening of soil solution to the soil surface). Topsoil horizons are characterized by relatively low $\rho$ values due to high salt content with the most abundant most abundant halite and thenardite of seawater-derived origin, following by aragonite, calcite and gypsum (Gore and Leishman 2020). At the same time $\rho$ values in Bunger 1 site are lower for some thousand $\Omega . m$ compared to Bunger 2 site. It is caused by higher water content in Bunger 1 soil. Profile Bunger 1 site Permafrost table depth varies from $82 \mathrm{~cm}$ to $106 \mathrm{~cm}$. Deeper location of per-

\section{Larsemann Hills}

LarsJan1 site is located in the zone of active influence of stream water from melting snow patches in so-called "wet valleys" of Larsemann Hills. It explains very low $\rho$ values in upper $50 \mathrm{~cm}$ of soil. On the other hand, LarsJan8 site is situated less saturated position and $\rho$ profile is characterized by higher resistivity values. Cryoturbation is weakly pronounced in both soils, which is seen from $\rho$ profiles and also proved by soil morphology. Hence, profile curves of resistivity values are gradual. Permafrost depth was identified as $122 \mathrm{~cm}$ in LarsJan 1 and $95 \mathrm{~cm}$ in LarsJan8 site. This depth is quite higher than those reported for permafrost table by Mergelov (2014). This discrepancy is probably caused by seasonal variation of temperature in Larse- caused by changing of non-frozen friable debris to frozen massive crystalline rock.

mafrost table in Bunger 1 site is explained by the absence of organic layer, which provides thermal isolation. This leads to intensification of thawing process during the summer period. The role of organic material in providing thermal isolation of Antarctic soils was discussed previously (Abakumov and Andreev 2011). It should be noted that very little data on active layer and permafrost table depth are published for Bunger Hills and available now, only first steps on establishment of permanent monitoring site for active layer has been done. Gibson et al. (2002) mentioned that the active layer depth as well as location vegetation zones in Bunger Hills seem to be different mostly because of water availability.

mann Hills, observed warming during last two summer seasons and consequent increase of rates in melting of snow. According to the authors, the highest rate of thawing can be found at sites with predominance of loose fine-earth substrata on northern slopes and patterned grounds with thin algae organo-mineral horizons.

One significant difference between studied profiles was found in permafrost layer. LarsJan 1 site is characterized by permafrost layer with gradual increasing of $\rho$ values. However, permafrost layer in LarsJan8 site shows the complicated trend of changing gradual increase in $\rho$ values by sharp decrease, which may be caused by changing of frozen massive crystalline rock to non-frozen friable debris at some depths. 

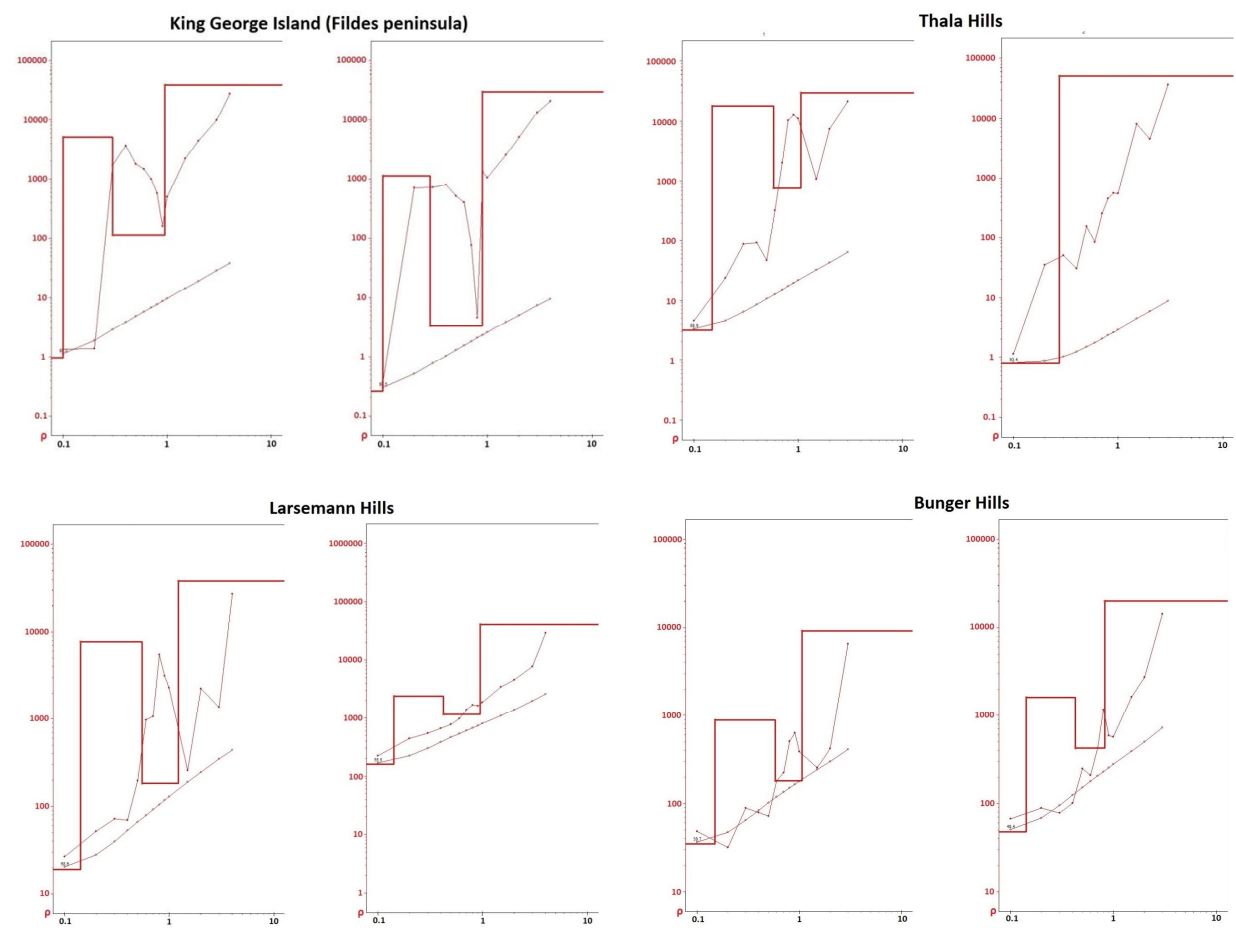

arsemann Hills
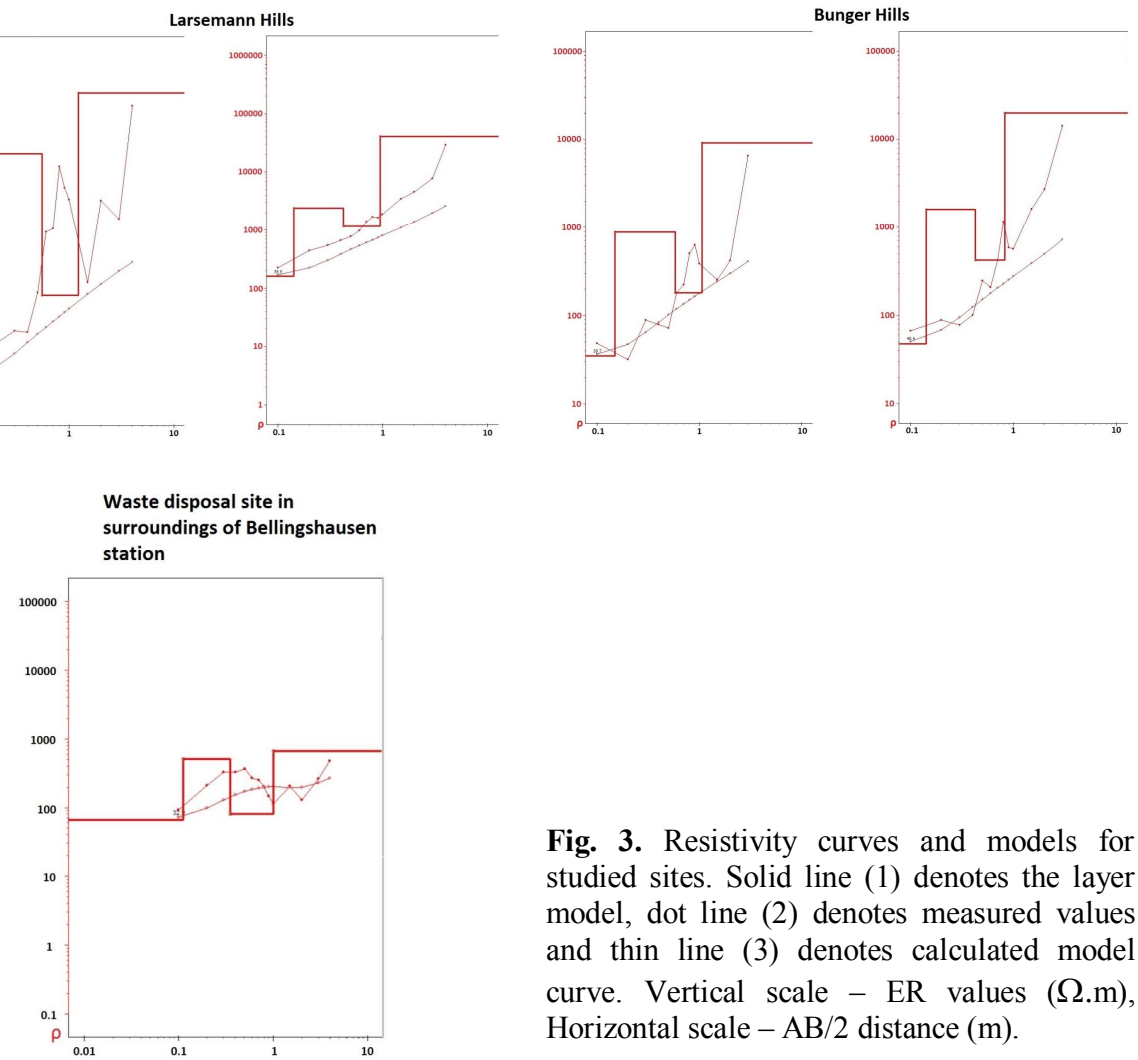

\section{Thala Hills}

Significant variation in permafrost table depth between studied sites in Thala Hills was caused mainly by different landscape position and amount of liquid water receiving from surrounding snow patches. Ant10 site is situated in the middle part of wellinsolated hill slope and receiving much

more water by overlying snow patch. That is why permafrost table depth here reaches $106 \mathrm{~cm}$ (compared to $27 \mathrm{~cm}$ at Ant2 site). This depth is quite higher than those reported for permafrost table by Dolgikh et al. (2015). 


\begin{tabular}{|c|c|c|}
\hline $\begin{array}{c}\text { P-modelled resistivity } \\
(\Omega . m)\end{array}$ & $\begin{array}{l}\text { Z-bottom layer depth } \\
\text { (m) }\end{array}$ & $\begin{array}{l}\text { Permafrost table depth } \\
\text { (m) }\end{array}$ \\
\hline \multicolumn{3}{|c|}{ King George Island } \\
\hline \multicolumn{3}{|c|}{$K G 1$} \\
\hline 0.26 & 0.10 & \multirow{4}{*}{0.89} \\
\hline 1129.62 & 0.18 & \\
\hline 3.29 & 0.61 & \\
\hline 29229.35 & 0.89 & \\
\hline \multicolumn{3}{|c|}{ Ardley 1} \\
\hline 116.89 & 0.087 & \multirow{4}{*}{1.00} \\
\hline 387.86 & 0.19 & \\
\hline 29.31 & 0.73 & \\
\hline 2743.55 & 1.0 & \\
\hline \multicolumn{3}{|c|}{ Thala Hills } \\
\hline \multicolumn{3}{|c|}{ Ant10 } \\
\hline 3.21 & 0.15 & \multirow{4}{*}{1.06} \\
\hline 17640.87 & 0.43 & \\
\hline 769.98 & 0.48 & \\
\hline 29286.46 & & \\
\hline \multicolumn{3}{|c|}{ Ant2 } \\
\hline 0.81 & 0.27 & \multirow{2}{*}{0.27} \\
\hline 50723.11 & & \\
\hline \multicolumn{3}{|c|}{ Larseman Hills } \\
\hline \multicolumn{3}{|c|}{ LarsJan1 } \\
\hline 19.03 & 0.14 & \multirow{4}{*}{1.22} \\
\hline 7659.33 & 0.41 & \\
\hline 183.04 & 0.68 & \\
\hline 38086.09 & & \\
\hline \multicolumn{3}{|c|}{ LarsJan8 } \\
\hline 159.82 & 0.14 & \multirow{4}{*}{0.95} \\
\hline 2377.80 & 0.28 & \\
\hline 1159.30 & 0.52 & \\
\hline 41012.54 & & \\
\hline
\end{tabular}




\begin{tabular}{|c|c|c|}
\hline \multicolumn{3}{|c|}{ Bunger Hills } \\
\hline \multicolumn{3}{|c|}{ Bunger 1} \\
\hline 34.61 & 0.15 & \multirow{4}{*}{1.06} \\
\hline 876.72 & 0.43 & \\
\hline 179.51 & 0.48 & \\
\hline 9151.52 & & \\
\hline \multicolumn{3}{|c|}{ Bunger 2} \\
\hline 47.82 & 0.14 & \multirow{4}{*}{0.82} \\
\hline 1620.05 & 0.28 & \\
\hline 420.13 & 0.40 & \\
\hline 20043.94 & & \\
\hline \multicolumn{3}{|c|}{ Waste disposal site, surroundings of Bellingshausen station } \\
\hline 66.23 & 0.11 & \multirow{4}{*}{1.0} \\
\hline 508.80 & 0.24 & \\
\hline 80.79 & 0.65 & \\
\hline 661.26 & 1.0 & \\
\hline
\end{tabular}

Table 3. Modelled resistivity and evaluated permafrost table depth.

Although, both profiles are characterized by low ER values in upper part, Ant2 shows much higher rate of cryoturbation. Hence, $\rho$ curve at this site is more complicated. It was revealed that in both profiles permafrost layer are quite homogeneous and described by monotonous increase of $\rho$ value. The data obtained coincided well with soil morphological properties de-

\section{Conclusions}

The methods of field electrophysics have been applied for the study of soil and permafrost layers of different regions in both Eastern and Western Antarctica. It was found that permafrost table depth ranged between 82 and $106 \mathrm{~cm}$ in Bunger Hills, 95 and $122 \mathrm{~cm}$ in Larsemann Hills, 27 and 106 in Thala Hills 89 and $100 \mathrm{~cm}$ on King George and Ardley Island. Pres- scribed during the field work. Relatively low values of electrical resistivity in upper horizons might be in some cases caused by high amount of water accumulated in porous media. In other cases sharp increasing of electrical resistivity values within the soil profile might be caused by specific properties of bedrock. ence (and thickness) of organic layer and influence of snow patches melting were found as the main factors for differentiation of permafrost table depth in studied ice-free areas. Anthropogenic disturbance at waste disposal site results in increasing of soil profile heterogeneity and formation of complicated electrical resistivity profiles due to mechanical soil disturbance and ap- 
pearance of artificial materials in soil profile.

Cryoturbation process and supra-permafrost accumulation of moisture which are widespread in the studied soils, lead to cryogenic mass transfer, heterogeneity of soil mass, and complication of the profile distribution of electrical resistivity values. The character of parent material determines temperature and water regime in soil, rate of cryopedogenesis, dynamics and thickness of active layer and permafrost table.

We have revealed two trends in profile distribution of electrical resistivity values within the permafrost layer. The first trend is connected with a constant increase in electrical resistivity values along the depth, which may be explained by an increase in electrical resistivity within the soil depth due to increase of permafrost density. The second trend caused by changing non-frozen friable debris to frozen massive crystalline rock. This explains that a sharp decrease of electrical resistivity is constituted by an increase in electrical resistivity due to bedrock freezing. In general, permafrost layer was found less homogenous in the upper part of permafrost strata compared to the lower part.

It can be concluded that application of VERS became useful for evaluation of soil thawing depth in case of permafrost-affected soils. Degradation of permafrost can affect the stability of building basement and constructions. Since that, VERS measurements can be used for permanent monitoring of the Antarctic stations with the aim of better understanding of human impact on permafrost stability and depth.

\section{References}

Abakumov, E., Parnikoza, I. (2015): Determination of the soil-permafrost border in selected plots of Antarctic Peninsula on the base of vertical electric sounding data. Ukranian Antarctic Journal, 14: 138-142.

Abakumov, E., Alekseev, I. (2018): Stability of soil organic matter in Cryosols of the maritime Antarctic: Insights from ${ }^{13} \mathrm{C}$ NMR and electron spin resonance spectroscopy. Solid Earth, 9: 1329-1339.

Abakumov, E., Andreev, M. (2011): Temperature regime of humus soil horizons of the KingGeorge Island. Transaction Saint-Petersburg University. Series 3, 2: 129-133.

ABAKumov, E., TOMASHunas, V. (2016): Electric resistivity of soils and upper permafrost layer of the Gydan Peninsula. Polarforschung, 86(1): 27-34.

Abramov, A., Sletten, R., Rivkina, E., Mironov, V. and Gilichinsky, D. (2011): Geocryological conditions of Antarctica. Earth's Cryosphere, 3: 3-19 (In Russian).

Alekseev, I., Kostecki, J. and ABAKumov, E. (2017): Vertical electrical resistivity sounding (VERS) of tundra and forest tundra soils of Yamal region. International Agrophysics, 31: 1-8.

Alekseev, I., ABAKumov, E. (2016): Vertical electrical sounding of soils and permafrost of marine terraces of Gronfjord (Svalbard archipelago). Czech Polar Reports, 6: 210-220.

André, F., van Leeuwen, C., Saussez, S., Van Durmen, R., Bogaert, P., Moghadas, D., De Resseguier, L., Delvaux, B., Vereecken, H. and Lambot, S. (2012): High-resolution imaging of a vineyard in south of France using ground-penetrating radar, electromagnetic induction and electrical resistivity tomography. Journal of Applied Geophysics, 78: 113-122.

Andrenelli, M.C., Magini, S., Pelegrini, S., Perria, R., Vignozzi, N. and Costantini, E. A. (2013): The use of the ARPC system to reduce the costs of soil survey for precision viticulture. Journal of Appied Geophysics, 99: 24-34.

Besson, A., Cousin, I., Samouelian, A., Boizard, H. and Richard, G. (2004): Structural heterogeneity of the soil tilled layer as characterized by 2D electrical resistivity surveying. Soil and Tillage Research, 79: 239-249. 
Black, L., Harley, S., Sun, S. and Mcculloch, M. (1987): The Rayner Complex of East Antarctica: Complex isotopic systematics within a Proterozoic mobile belt. Journal of Metamorphic Geology, 5: 1-26.

BockHeIM, J., HALL, K. (2002): Permafrost, active-layer dynamics and periglacial environments of continental Antarctica. South-African Journal of Science, 98: 82-90.

Burgess, M.M., Smith, S.L., Brown, J., Romanovsky, V. and Hinkel, K. (2000): Global Terrestrial Network for Permafrost (GTNet-P) permafrost monitoring contributing to global climate observations. Geological Survey of Canada, Current Research, 14: 1-7.

Colmoun, A., AdAmson, A. (1992): Raised Beaches of the Bunger Hills. ANARE Reports No. 136: $47 \mathrm{pp}$.

Dolgikh, A., Mergelov, N., Abramov, A., Lupachev, A. and Goryachkin, S. (2015): Soils of Enderby Land. In: J. G. Bockheim (ed.): The Soils of Antarctica. Basel Springer International, pp. 45-63.

Gilichinsky D., Abakumov E., Abramov A. Fyodorov-Davydov D., Goryachkin S., Lupachev A., Mergelov N. and Zazovskaya, N. (2010): Soils of mid and low antarctic: diversity, geography, temperature regime. $19^{\text {th }}$ World Congress of Soil Science, Soil Solutions for a Changing World, Conference Proceedings, pp. 32-35.

GiBAS, J., RACHLEWICZ, G. and SzCZUCINSKI, W. (2005): Application of DC resistivity soundings and geomorphological surveys in studies of modern Arctic glacier marginal zones, Petuniabukta, Spitsbergen. Polish Polar Research, 26 (4): 239-258.

Gibson, J., GoRE, D. and Kaup, E. (2002): Algae River: An extensive drainage system in the Bunger Hills, East Antarctica. Polar Record, 38(205): 141-152.

Gore, D., Leishman, M. (2020): Salt, sediments and weathering environments in Bunger Hills. Antarctic Science, 32(2): 138-152.

Hauck, C., Muhll, D. V. and Maurer, H. (2003): Using DC resistivity tomography to detect and characterize mountain permafrost. Geophysycal. Prospecting, 51: 273-284.

HrbáčEK, F., Viera, G., Oliva, M., BalKs, M. and Guglielmin M. (2018): Active layer monitoring in Antarctica: an overview of results from 2006 to 2015. Polar Geography, doi: 10.1080/1088937X.2017.1420105.

Jaynes, D. B., Colvin, T., Kaspar, T. (2005): Identifying potential soybean management zones from multi-year yield data. Computers and Electronics in Agriculture, 46: 309-327. doi: 10.1016/j.compag.2004.11.011

KARLIK, G., KAYA, A. M. (2001): Investigation of groundwater contamination using electric and electromagnetic methods at an open waste-disposal site: a case study from Isparta, Turkey. Environmental Geology, 40: 725-731.

KASPRZAK, M. (2015): High-resolution electrical resistivity tomography applied to patterned ground, Wedel Jarlsberg Land, south-west Spitsbergen. Polar Research, 34: 1. doi: 10.3402/ polar.v34.25678.

Magnin, F., Krautblatter, M., Deline, P., Ravanel, L., Malet, E. and Bevington, A. (2015): Determination of warm, sensitive permafrost areas in near-vertical rockwalls and evaluation of distributed models by electrical resistivity tomography. Journal of Geophysical Research, 120(5): 745-762.

Marchenko, M. N. (2007): Manual on Vertical Electric Sounding. Moscow State University, Moscow, 30 p. (In Russian).

MCGINIS, L.D., JENSEN, T.E. (1971): Permafrost-hydrogeologic regimen in two ice-free valleys, Antarctica, from electrical depth sounding. Quaternary Research, 1: 389-409.

Mergelov, N. (2014): Soils of wet valleys in the Larsemann Hills and Vestfold Hills oases (Princess Elizabeth Land, East Antarctica). Eurasian Soil Science, 47 (9): 845-862.

Mergelov, N., Konyushkov, D., Lupachev, A. and Goryachkin, S. (2015): Soils of MacRobertson Land. In: Bockheim J.G. (ed.): The Soils of Antarctica. Springer International, Basel, pp. 65-86.

Michel, R., Schaefer, C., Dias, L., Simas, F., Benites, V. and Mendonca, E. (2006): Ornithogenic gelisols (cryosols) from Maritime Antarctica: pedogenesis, vegetation and carbon studies. Soil Science Society of America Journal, 70: 1370-1376. 
Michels Turu, I.V., Ros Visus, X. (2013): Geophysical survey carried out in the Hansbreen glacial front (Hornsund, SW Spitzberguen): Surface Nuclear Magnetic Resonance (SNMR), Magnetic susceptibility of rocks and Electrical Resistivity facies: Permafrost identification and subglacial aquifers. IV Congreso Ibérico de la I.P.A. Núria (Vall de Ribes, Pirineo oriental).

MuRAD, O. M. (2012): Obtaining Chemical Properties through Soil Electrical Resistivity. Journal of Civil Engineering Research, 2(6): 120-128.

Oliva, M., Navarro, F., Hrbacek, F., Hernandez, A., Nyvlt, D., Pereira, P., Ruiz Fernandez, J. and TRIGO, R. (2017): Recent regional climate cooling on the Antarctic Peninsula and associated impacts on the cryosphere. Science of Total Environment, 580: 210-223.

Petterson, J. K., Nobes, D. (2003): Environmental geophysics at Scott Base: ground penetrating radar and electromagnetic induction as tools for mapping contaminated ground at Antarctic research bases. Cold Regions Science and Technology, 37 (2): 187-195.

POZDNYAKOV, A. I. (2008): Electrical soil parameters and soil formation process. Pochvovedenie, 10: 1188-1197. (In Russian).

Samouëlian, A., Cousin, I., Tabbagh, A., Bruand, A. and Richard, G. (2005): Electrical resistivity survey in soil science: A review. Soil and Tillage Research, 83: 173-193.

Simas, N., Schaefer, C., Mendonca, E., Silva, I. and Ribeiro, A. (2007): Organic carbon stocks in permafrost-affected soils from Admiralty Bay, Antarctica. Journal of research of the U.S. Geological Survey, 1047: 76-79.

Smernikov, S.A., Pozdnyakov, A. I. and Shein, E. V. (2008): Assessment of Soil Flooding in Cities by Electrophysical Methods. Eurasian Soil Science, 41: 1059-1065.

Terauds, A., Chown, S., Morgan, F., Peat, H., Watts, D., Keys, H., Convey, P. and Bergstrom, D. (2012): Conservation biogeography of the Antarctic. Diversity and Distributions, 18: 726-741. doi:10.1111/j.1472-4642.2012.00925.x

Tetegan, M., Pasquier, C., Besson, A., Nicoullaud, B., Bouthier, B., Bourenane, H., Desbourdes, C., King, D. and Cousin, I. (2012): Field-scale estimation of the volume percentage of rock fragments in stony soils by electrical resistivity. Catena, 92: 67-74.

TRIANTAFALIS, J., LeSCH, S. M. (2005): Mapping clay content variation using electromagnetic induction techniques. Computers and Electronics in Agriculture, 46: 203-237.

VANHALA, H., LINTINEN, P. and OJALA, A. (2009): Electrical Resistivity Study of Permafrost on Ridnitohkka Fell in Northwest Lapland, Finland. Geophysica, 45(1-2): 103-118.

Viera, G., Ramos, M., Gruber, S., Hauck, C. and Blanco, J. (2007): The permafrost environment of northwest Hurd Peninsula (Livingston Island, maritime Antarctic): Preliminary results. USGS OF-2007-1047, Extended Abstract 2, U.S. Geological Survey and the National Academies.

\section{Web sources / Other sources}

[1] ROSHYDROMET, http://www.wmo.int/pages/prog/www/Antarctica

[2] World reference base for soil resources (2014): Rome, FAO: 203 p. 